\section{Data on sand fly fauna (Diptera, Psychodidae, Phlebotominae) in Itatiaia National Park, Rio de Janeiro State, Brazil}

\author{
Dados sobre a fauna flebotomínica (Diptera, \\ Psychodidae, Phlebotominae) do Parque Nacional \\ de Itatiaia, Estado do Rio de Janeiro, Brasil
}

Margarete M. S. Afonso 1

Wagner A. Costa ${ }^{2}$

Alfredo C. R. Azevedo 1

Simone M. da Costa 1

Maurício L. Vilela 1

Elizabeth F. Rangel 1

\footnotetext{
I Instituto Oswaldo Cruz, Fundação Oswaldo Cruz, Rio de Janeiro, Brasil. 2 Secretaria de Vigilância em Saúde, Ministério da Saúde, Brasília, Brasil.

Correspondence E. F. Rangel Deptartamento de Entomologia, Instituto Oswaldo Cruz, Fundação Oswaldo Cruz. Av. Brasil 4365, Rio de Janeiro, RJ 21045-900, Brasil. elizabethrangel@fiocruz.br
}

\begin{abstract}
The sand fly fauna in Itatiaia National Park, Rio de Janeiro, Brazil, was investigated in different habitats ranging from sylvatic areas to those altered by human activity related to ecotourism, specifically identifying species that have been suggested as potential leishmaniasis vectors. Sand flies were captured from June 2002 to March 2004, using CDC light traps and Shannon traps. A total of 1,256 sand fly specimens were captured, from species belonging to genera Lutzomyia and Brumptomyia: Brumptomyia guimaraesi, B. troglodytes, Lutzomyia (Lutzomyia) amarali, L. lanei, L. migonei, L. sallesi, L. edwardsi, L. tupynambai, L. (Pintomyia) pessoai, L. (P.) bianchigalatie, L. rupicola, L. (Psathyromyia) shannoni, L. pascalei, L. (Psychodopygus) matosi, L. (P.) davisi, L. (P.) hirsuta hirsuta, L. (P.) ayrozai, L. peresi, L. monticola, and $\mathrm{L}$. misionensis. Worthy of special attention were four species that are considered potential vectors for cutaneous leishmaniasis in Brazil: L. ayrozai, L. hirsuta hirsuta, L. migonei, and L. davisi, representing $19.19 \%$ of the specimens captured in this study.
\end{abstract}

Psychodidae; Leishmaniasis; Disease Vectors

\section{Introduction}

Itatiaia National Park in Rio de Janeiro State is the oldest officially demarcated environmental conservation unit in Brazil and is characterized by considerable biodiversity, while still presenting inexhaustible potential for developing research in various fields of knowledge.

As recommended previously in the Handbook for Surveillance and Control of Visceral Leishmaniasis published by the Health Surveillance Secretariat of the Brazilian Ministry of Health 1, entomological surveys aim to obtain quantitative and qualitative information on sand fly vectors with the key objective of verifying vector presence in locations and municipalities (or counties) without human cases (so-called "silent" municipalities).

The current study assesses the presence of sand fly species in environments that have been ecologically altered by human activity and identifies potential leishmaniasis vectors in Itatiaia National Park.

\section{Materials and methods}

\section{Study area description}

Itatiaia National Park is a federal conservation unit that was created in June 14, 1937, as Brazil's first national park. It is located in the Itatiaia 
Massif on the highest portion of the Mantiqueira mountain range, in southwestern Rio de Janeiro State, on land located in the municipalities of Resende and Itatiaia, and in southern Minas Gerais State, in the municipalities of Bocaina de Minas, Alagoa, and Itamonte (Figure 1), between latitudes $22^{\circ} 19^{\prime}$ and $22^{\circ} 45^{\prime} \mathrm{S}$ and longitudes $44^{\circ} 45^{\prime}$ and $44^{\circ} 50^{\prime}$ 'W.Gr. With altitudes varying from 700 to $2,787 \mathrm{~m}$ and peaks including Agulhas Negras, the fifth highest in Brazil 2, the Park extends along a $10 \mathrm{~km}$-wide strip with a total area of 120,000 hectares.

Itatiaia National Park has a mesothermal climate and a mountainous and rocky relief, thus the original name (Itatiaia means "rock full of points" in the indigenous Tupi-Guarani language). With such variation in altitudes, the region displays different types of vegetation, such as the Moun-

Figure 1

Map with the location of Itatiaia National Park, States of Rio de Janeiro and Minas Gerais, Brazil. June 2002-March/2004. (A) Stations of sand fly collections and (B) some informations about the Itatiaia National Park.
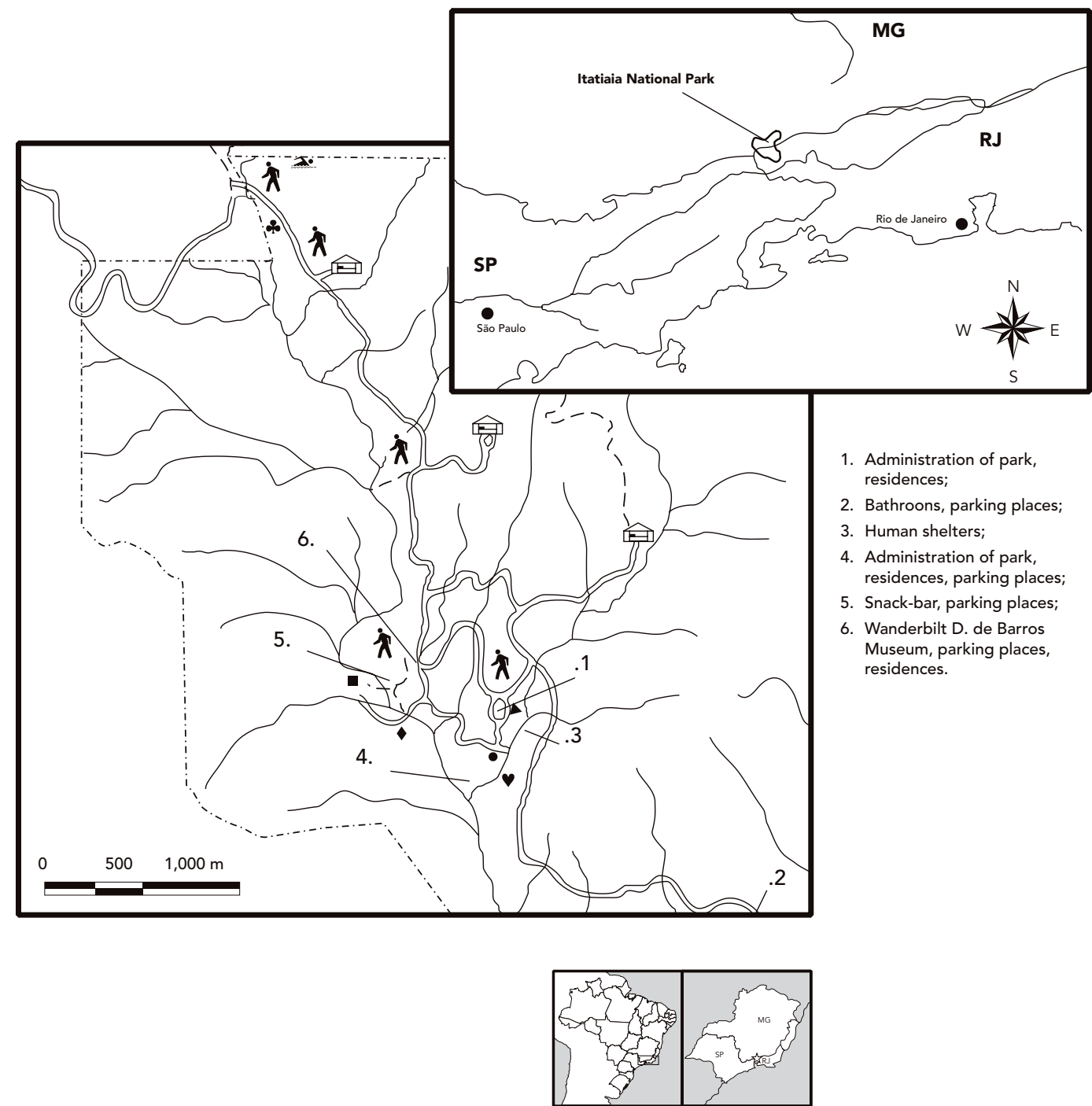

(A) $\Delta$ Station I; • Station II; $\bullet$ Station III; Station IV; $\bullet$ Station V; * Station VI

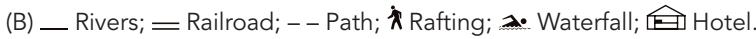


tainous Atlantic Rainforest and the Mountainous Dense Ombrophilous Forest.

\section{Sand fly captures}

Sand flies were captured from June 2002 to June 2003, three times a month, and from July 2003 to February 2004, twice a month, except for December 2002, January 2003, November 2003, and February 2004, at six stations distributed along the lower portion of Itatiaia National Park: Station I (Pedra Fundamental), Station II (Atalho da Brigada), Station III (shelters for hikers/climbers), Station IV (barbecue pits), Station V (Blue Lake), and Station VI (Véu da Noiva Waterfall) (Figure 1), using a total of five CDC-type light traps ${ }^{3}$ at Stations I, II, III, IV, and V, from 18:00 to 6:00h and Shannon traps ${ }^{4}$ at Stations I, V, and VI from 18:00 to 20:00h. Capture time totaled 2,020 hours (40 with Shannon traps and 1,980 with CDC light traps).

Duringcaptures, mean temperature remained close to $16.7^{\circ} \mathrm{C}$, ranging from $8^{\circ} \mathrm{C}$ to $29.5^{\circ} \mathrm{C}$, while relative humidity ranged from 72 to $93 \%$, with a mean of approximately $83.72 \%$, and annual rainfall ranged from 1,800 to $2,100 \mathrm{~mm}$.

The sand flies were identified as follows, as proposed by Young \& Duncan 5 .

Evaluation of anthropophilic species included the sand flies that bit the collectors who were using the Shannon trap.

The study is the result of an agreement between the Oswaldo Cruz Foundation (FIOCRUZ) and the Brazilian Institute of the Environment and Renewable Resources (IBAMA) (Technical Cooperation Term no. 12/2002) and received Environmental Conservation Unit Research Permit no. 153/2003.

\section{Results}

A total of 1,256 sand flies (Table 1) were collected in 2,020 capture hours, including the following: Brumptomyia guimaraesi (Coutinho \& Barreto, 1941), B. troglodytes (Lutz, 1922), Lutzomyia (Lutzomyia) amarali (Barreto \& Coutinho, 1940),

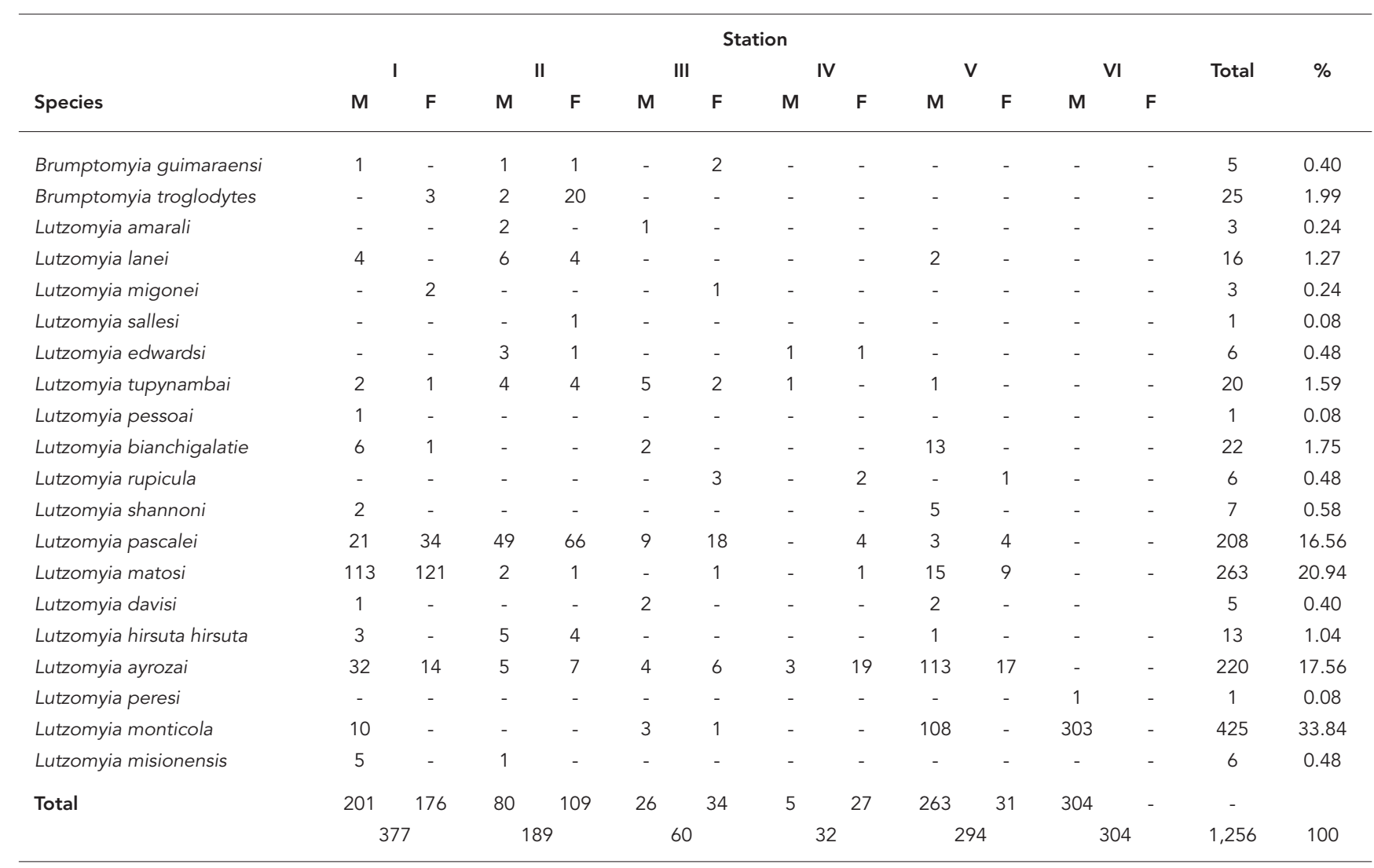

$\mathrm{M}=$ male; $F=$ female. 
L. lanei (Barreto \& Coutinho, 1941), L. migonei (França, 1920), L. sallesi (Galvão \& Coutinho, 1939), L. edwardsi (Mangabeira, 1941), L. tupynambai (Mangabeira, 1942), L. (Pintomyia) pessoai (Coutinho \& Barreto, 1940), L. (P.) bianchigalatie (Andrade-Filho, Aguiar, Dias \& Falcão, 1999), L. rupicola (Martins, Godoy \& Silva, 1962), L. (Psathyromyia) shannoni (Dyar, 1929), L. pascalei (Coutinho \& Barreto, 1940), L. (Psychodopygus) matosi (Barreto \& Zago, 1956), L. (P.) davisi (Root, 1934), L. (P.) hirsuta hirsuta (Mangabeira, 1942), L. (P.) ayrozai (Barreto \& Coutinho, 1940), L. peresi (Mangabeira, 1942), L. monticola (Costa Lima, 1932), and L. misionensis (Castro, 1959).

Tables 1 and 2, respectively, show the distribution of species by capture station and capture method.

Among the sand fly species identified, there was a predominance of L. monticola $(33.84 \%)$, followed by L. matosi (20.94\%), L. ayrozai (17.56\%), and L. pascalei (16.56\%) (Table 1).

\section{Discussion}

Worthy of special attention were four species that are considered potential vectors of cutaneous leishmaniasis in Brazil: L. ayrozai, L. hirsuta hirsuta, L. migonei, and L. davisi, representing $19.19 \%$ of the specimens captured in this study.

L. ayrozai is known as a highly anthropophilic species in the mountainous region of Southeast Brazil. During recent studies performed at the Poço das Antas Biological Reserve in the State of Rio de Janeiro 6, L. ayrozai comprised a large proportion $(40.1 \%)$ of the sand fly species captured. However, thus far the species' epidemiological importance has been limited to the Amazon region, where it is considered a vector of Leishmania (Viannia) naiffi 7 .

The importance of $L$. davisi as a cutaneous leishmaniasis vector in the State of Rondônia, Brasil, was recently discussed by Gil et al. ${ }^{8}$. In an endemic area where it predominated (39.6\%), the

Distribution of sand fly species according to capture methodology. Itatiaia National Park, Rio de Janeiro State, Brazil. June 2002-March 2004.

\begin{tabular}{|c|c|c|c|c|c|c|c|}
\hline \multirow[b]{2}{*}{ Species } & \multicolumn{2}{|c|}{ Light traps } & \multicolumn{2}{|c|}{ Shannon trap } & \multicolumn{2}{|c|}{ Biting humans } & \multirow[t]{2}{*}{ Total } \\
\hline & M & $\mathbf{F}$ & M & $\mathbf{F}$ & M & $\mathbf{F}$ & \\
\hline Brumptomyia guimaraesi & 2 & 3 & - & - & - & - & 5 \\
\hline Brumptomyia troglodytes & 2 & 23 & - & - & - & - & 25 \\
\hline Lutzomyia amarali & 3 & - & - & - & - & - & 3 \\
\hline Lutzomyia lanei & 12 & 4 & - & - & - & - & 16 \\
\hline Lutzomyia migonei & - & 3 & - & - & - & - & 3 \\
\hline Lutzomyia sallesi & - & 1 & - & - & - & - & 1 \\
\hline Lutzomyia edwardsi & 4 & 2 & - & - & - & - & 6 \\
\hline Lutzomyia tupynambai & 13 & 7 & - & - & - & - & 20 \\
\hline Lutzomyia pessoai & 1 & - & - & - & - & - & 1 \\
\hline Lutzomyia bianchigalatie & 2 & - & 8 & 1 & 11 & - & 22 \\
\hline Lutzomyia rupicola & - & 6 & - & - & - & - & 6 \\
\hline Lutzomyia shannoni & 2 & - & 2 & - & 3 & - & 7 \\
\hline Lutzomyia pascalei & 78 & 101 & 4 & 25 & - & - & 208 \\
\hline Lutzomyia matosi & 13 & 13 & 117 & 120 & - & - & 263 \\
\hline Lutzomyia davisi & 2 & - & 3 & - & - & - & 5 \\
\hline Lutzomyia hirsuta hirsuta & 5 & 4 & 3 & - & 1 & - & 13 \\
\hline Lutzomyia ayrozai & 21 & 46 & 45 & 14 & 91 & 3 & 220 \\
\hline Lutzomyia peresi & - & - & - & - & 1 & - & 1 \\
\hline Lutzomyia monticola & 13 & 1 & - & 89 & 322 & - & 425 \\
\hline Lutzomyia misionensis & 6 & - & - & - & - & - & 6 \\
\hline Total & 175 & 216 & 271 & 160 & 431 & 3 & 1,256 \\
\hline
\end{tabular}

$\mathrm{M}=$ male; $\mathrm{F}=$ female. 
species proved to be highly anthropophilic and was found naturally infected with $L$. (V.) naiffi.

L. hirsuta hirsuta has been recorded in the State of Rio de Janeiro in areas where the plant cover is still preserved. In 1985, L. h. hirsuta was found naturally infected with Leishmania (Viannia) sp. in Além Paraíba, Minas Gerais State 9 . In a cutaneous leishmaniasis transmission area in the State of Rondônia, this sand fly was found naturally infected with $L$. (V.) naiffi according to preliminary analyses with monoclonal antibodies 8 .

L. migonei, which has already been recorded in the State of Rio de Janeiro 7, is known to be an anthropophilic species and can be captured biting domestic animals, especially dogs, and may also bite wild animals. The role of L. migonei in the transmission of Leishmania (Viannia) braziliensis was initially well characterized in Northeast Brazil, where it invades human dwellings, biting humans, and was found naturally infected with $L$. (V.) braziliensis in Baturité, Ceará State 7,10,11, In the State of Rio de Janeiro, considering its anthropophilic habits and the fact that it was recently found naturally infected with $L$. (V.) braziliensis at the Juliano Moreira mental health facility in Jacarepaguá 12 , the species could be considered a secondary cutaneous leishmaniasis vector.

In a comparative analysis, the captures performed at Pedra Fundamental (Station I) produced more species and specimens, with a high frequency of L. matosi. Interestingly, the captures at Véu de Noiva Waterfall (Station VI) produced a limited diversity of species (only two) but included the second largest number of specimens.

Some species were collected biting humans: L. bianchigalatie, L. hirsuta hirsuta, L. ayrozai, and especially L. monticula (Table 2). Of the 425 specimens captured, $76.4 \%$ were biting humans.

\section{Resumo}

A fauna flebotomínica do Parque Nacional de Itatiaia, Rio de Janeiro, Brasil, foi investigada, em diferentes ambientes, envolvendo áreas silvestres e os ambientes ecologicamente alterados, principalmente por atividades ligadas ao ecoturismo, identificando espécies potencialmente vetoras de leishmanioses. As coletas de flebotomíneos foram realizadas no referido parque, no período de junho de 2002 a março de 2004, com armadilhas luminosas do tipo CDC e armadilha de Shannon. Foram coletados 1.256 flebotomíneos, correspondendo às seguintes espécies: Brumptomyia guimaraesi, B. troglodytes, Lutzomyia (Lutzomyia) amarali, L. lanei, L. migonei, L. sallesi, L. edwardsi, L. tupynambai, L. (Pintomyia) pessoai, L. (P.) bianchigalatie, L. rupicola, L. (Psathyromyia) shannoni, L. pascalei, L. (Psychodopygus) matosi, L. (P.) davisi, L. (P.) hirsuta hirsuta, L. (P.) ayrozai, L. peresi, L. monticola $e$ L. misionensis. Merecem especial atenção por sua importância epidemiológica L.ayrozai, L. hirsuta hirsuta, L. migonei $e$ L. davisi, representando $19,19 \%$ dos exemplares capturados.

Psychodidae; Leishmaniose; Vetores de Doenças

\section{Contributors}

E. F. Rangel, A. C. R. Azevedo, M. M. S. Afonso, M. L. Vilela, S. M. Costa, and W. A. Costa, participated in the fieldwork (sand fly captures), taxonomy (specimen identification), and analysis of the results.

\section{Acknowledgements}

The authors wish to thank Daniel Motta of the Department of Entomology, Oswaldo Cruz Institute, Oswaldo Cruz Foundation, and Jonas Ferreira Manf Group for preparing the maps, and Léo Nascimento, Director of the Itatiaia National Park for his cooperation during the fieldwork. 


\section{References}

1. Secretaria de Vigilância em Saúde, Ministério da Saúde. Manual de vigilância e controle de leishmaniose visceral. Brasília: Ministério da Saúde; 2003.

2. Instituto Brasileiro de Geografia e Estatística. Anuário estatístico do Brasil. v. 56. Rio de Janeiro: Instituto Brasileiro de Geografia e Estatística; 1998.

3. Sudia WD, Chamberlain RW. Battery operated light trap, an improved model. Mosquito News 1962; 22:126-9.

4. Shannon RC. The occurrence of Phlebotomus in Panama. J Wash Acad Sci 1926; 16:190-3.

5. Young DC, Duncan NA. Guide to the identification and geographic distribution of Lutzomyia sandflies in México, the West Indies, Central and South America (Diptera: Psychodidae). Memoirs of the American Entomological Institute 1994; 54:1-881.

6. Souza NA, Andrade-Coelho CA, Vilela ML, Rangel EF. The Phlebotominae sand fly (Diptera: Psychodidae) fauna of two Atlantic Rain Forest Reserves in the State of Rio de Janeiro, Brazil. Mem Inst Oswaldo Cruz 2001; 96:319-24.

7. Rangel EF, Lainson R. Ecologia das leishmanioses: transmissores de leishmaniose tegumentar americana. In: Rangel EF, Lainson R, organizadores. Flebotomíneos do Brasil. Rio de Janeiro: Editora Fiocruz; 2003. p. 291-310.

8. Gil LHS, Basano SA, Souza AA, Silva, MGS, Barata I, Ishikawa $\mathrm{E}$, et al. Recent observations on the sand fly (Diptera: Psychodidae) fauna of the State of Rondônia, Western Amazônia, Brazil: the importance of Psychdopygus davisi as a vector of zoonotic cutaneous leishmaniasis. Mem Inst Oswaldo Cruz 2003; 98:751-5.
9. Rangel EF, Ryan L, Lainson R, Shaw J. Observations on the sandfly (Diptera: Psychodidae) fauna of Além Paraíba, State of Minas Gerais, Brazil, and the isolation of a parasite of the Leishmania braziliensis complex from Psychodopygus hirsuta hirsuta. Mem Inst Oswaldo Cruz 1985; 78:235-6.

10. Azevedo ACR, Rangel EF, David J, Vasconcelos AW, Lopes UG. Natural infection of Lutzomyia (Nyssomyia) whitmani (Antunes \& Coutinho, 1939) by leishmania of the braziliensis complex in Baturite, Ceará State, Northeast Brazil. Mem Inst Oswaldo Cruz 1990; 85:251.

11. Queiroz RG, Vasconcelos IA, Vasconcelos AW, Pessoa FA, Souza RN, David JR. Cutaneous leishmaniasis in Ceará State in northeastern Brazil: incrimination of Lutzomyia whitmani (Diptera: Pshycodidae) as a vector of Leishmania braziliensis in Baturité municipality. Am J Trop Med Hyg 1994; 50:693-8.

12. Pita-Pereira D, Alves CR, Souza MB, Brazil RP, Bertho AL, Figueiredo-Barbosa A, et al. Identification of naturally infected Lutzomyia intermedia and Lutzomyia migonei with Leishmania (Viannia) braziliensis in Rio de Janeiro (Brazil) revealed by a PCR multiplex non-isotopic hybridisation assay. Trans R Soc Trop Med Hyg 2005; 99:905-13.

Submitted on 10/Aug/2005

Final version resubmitted on 24/Jul/2006

Approved on 01/Aug/2006 